\title{
Total kalça artroplastisinin başarısız olma mekanizmaları
}

\author{
Failure mechanisms of total hip arthroplasty
}

\author{
Fahri Emre ${ }^{1}$, Enes Uluyardımcı ${ }^{2}$, Çetin Işı $k^{3}$ \\ ${ }^{1}$ Gülhane Eğitim ve Araştırma Hastanesi, Ortopedi ve Travmatoloji Kliniği, Ankara \\ ${ }^{2}$ Develi Hatice - Muammer Kocatürk Devlet Hastanesi, Ortopedi ve Travmatoloji Kliniği, Kayseri \\ ${ }^{3}$ Memorial Ataşehir Hastanesi, Ortopedi ve Travmatoloji Kliniği, İstanbul
}

\begin{abstract}
Total kalça artroplastisi (TKA) özellikle son 25 yılda uygulanan en başarılı cerrahi işlemlerden biridir. Giderek artan primer TKA ameliyatları sayısı nedeniyle özellikle son 10 yılda revizyon kalça artroplastisi cerrahisinde de ciddi artış görülmektedir. Hastaların daha uzun ve kaliteli yaşam beklentisiyle birlikte, genç hastalara da TKA uygulamalarının giderek yaygınlaşması nedeniyle revizyon kalça artroplastisi sayılarının önümüzdeki 10 yılda en az iki kat artması beklenmektedir. Başarısızlığın nedenlerini anlamak; araştırma, klinik karar verme ve sağlık hizmetleri politikasına rehberlik etme açısından önemlidir. Semptomatik TKA'sı olan bir hastada ağrının kaynağına, sistematik ve kapsamlı bir şekilde yaklaşılmalıdır. Ayrıntılı bir öykü ve fizik muayene genellikle doğru tanıyı koydurabilir. Fizik muayenede her iki kalça, dizler ve omurga değerlendirilmelidir. Enfeksiyon için serolojik testler, gerekirse eklem artrosentezi ve standart radyografilerle birlikte yapılmalıdır. Bilgisayarlı tomografi (BT); özellikle implant pozisyonu, kemik kaybı, osteoliz, insert aşınması ve metallozis değerlendirilmesinde yararlıdır. Manyetik rezonans (MR) görüntüleme yumuşak dokuları değerlendirmek için uygundur. Tc-99 m gibi bir nükleer tıp taraması ameliyat sonrası ikinci yıla kadar yanlış pozitiflik gösterebilir ancak enfeksiyon ile aseptik gevşeme veya stres kırığı arasında ayrım yapmak için In-111 lökosit taraması ile birleştirilebilir. Ameliyat öncesi tanı konulmadan cerrahi yapılmamalıdır.
\end{abstract}

Anahtar sözcükler: revizyon kalça artroplastisi; total kalça artroplastisi; aseptik gevşeme; osteoliz; enfeksiyon; instabilite
Total hip arthroplasty (THA) is one of the most successful surgical procedures performed in the last 25 years. Due to the increasing number of THA surgeries, there has been a significant increase in revision hip arthroplasty surgery, especially in the last 10 years. The number of revision hip arthroplasty is expected to increase at least twice in the next 10 years due to the longer and higher quality life expectancy of the patients and the increasing prevalence of THA applications to younger patients. Understanding the causes of failure is important for research, clinical decision making, and guiding health care policy. In a patient with symptomatic THA, the source of pain should be approached systematically and comprehensively. A detailed history and physical examination can usually make the correct diagnosis. On physical examination, both hips, knees, and spine should be evaluated. Serological testing for infection should be performed with joint arthrocentesis and standard radiographs if necessary. Computed tomography $(C T)$ is particularly useful in evaluating implant position, bone loss, osteolysis, insert wear, and metallosis. Magnetic resonance imaging (MRI) is suitable for evaluating soft tissues. A nuclear medicine scan such as Tc-99 m may show false positives up to the second postoperative year but can be combined with an In-111 leukocyte scan to differentiate between infection and aseptic loosening or stress fracture. Surgery should not be performed without preoperative diagnosis.

Key words: revision hip arthroplasty; total hip arthroplasty; aseptic loosening; osteolysis; infection; instability
T otal kalça artroplastisi (TKA) özellikle son 25 yılda uygulanan en başarılı cerrahi işlemlerden biridir. Hastanın yaşam kalitesini önemli derece artırdığı gösterilmiştir. Giderek artan TKA ameliyatları, hastaların daha uzun ve kaliteli yaşam beklentisi ve kısıtlı teknolojik şartlardan dolayı revizyon kalça artroplastisi cerrahisinde artış görülmektedir. ${ }^{[1]}$ TKA'da başarısızlığın nedenini anlamak, gelecekteki stratejilere rehberlik etmede önemlidir. Herhangi bir nedenden dolayı yeniden ameliyat genellikle başarısızlık olarak kabul edilir. Total kalça artroplastisinin başarısızlığı, ortopedi ve travmatoloji uzmanları ve hastalar için klinik zorluklara yol açar.

Yıllarca iyi işlev gördükten sonra revize edilen kalça artroplastisi başarısızlık olarak kabul edilir ve artroplasti alanındaki geçmiş teknolojinin yetersizliğini gösterir. Teknolojideki ilerlemelerle birlikte aseptik gevşeme, aşınma ve osteoliz oluşumu azalacak; enfeksiyon,

iletişim / Contact: Op. Dr. Fahri Emre • E-posta / E-mail: faemre@gmail.com

ORCID iD: Fahri Emre, 0000-0002-6942-8051 • Enes Uluyardımcı, 0000-0002-0068-2852 • Çetin Işık, 0000-0002-5128-1602 
tekrarlayan instabilite ve materyal yetmezliği gibi daha az sıklıkla görülen yeniden ameliyat nedenleri nispeten belirgin hale gelecektir.

\section{YENIDEN AMELIYAT (REVIZYON) NEDENLERi}

İsveç ulusal kalça artroplastisi kaydı, 1979'dan 2003'e kadar İsveç'te toplam revizyon TKA sayısının (bir veya her iki komponentin veya protezin herhangi bir bölümünün değiştirilmesi veya çıkarılmasını içeren) 21.367 olduğunu ve bunun $17.881^{\prime}$ 'inin (\%84) ilk revizyon olduğunu bildirdi. Revizyon endikasyonları \%73,9 aseptik gevşeme, \%7,9 derin enfeksiyon, $\% 7,5$ çıkı, \%5,7 periprostetik kırık, \%2,5 teknik hata, \%1,5 implant kırığı ve \%0,3 ağıı idi. ${ }^{[2]}$ Amerika Birleşik Devletleri'nde Clohisy ve ark. tarafından 1996 - 2003 yılları arasında 430 revizyon rapor edilmiştir. Bu olgular içerisinde \%55 aseptik gevşeme, \%14 instabilite, $\% 13$ iyi sabitlenmiş implantlarla osteoliz, \%7 enfeksiyon, $\% 5$ periprostetik kırık, $\% 1$ yumuşak doku sıkışması ve $\% 1$ implant kırılması tespit edildi. ${ }^{[3]}$

\section{Osteoliz (Aseptik Gevşeme)}

Osteoliz (aseptik gevşeme), orta ve uzun dönem kalça artroplastisi başarısızıı̆ının en önemli nedenidir. ${ }^{[4]}$ Osteoliz, aşınan partiküllere hücresel yanıt sonrası oluşan kemik rezorpsiyonudur. ${ }^{\left[{ }^{3}\right]}$ Eklemleşme veya tespit yönteminden bağımsız olarak herhangi bir protezi etkileyebilir. Yaş, cinsiyet, kilo ve aktivite düzeyi gibi hasta faktörleriyle de ilişkilendirilmiştir. Partiküllerin; biyoreaktivitesine, boyutlarına, bileşimlerine ve konsantrasyonlarına bağlıdır. ${ }^{[6]}$ Aseptik gevşemeyi açıklamak için yıllar içinde mikro hareket ve stres kalkanından, sıvı basıncı ve endotoksinlere kadar çeşitli teoriler önerilmiştir. ${ }^{[7]}$ Osteolize yol açan biyolojik yanıtın merkezinde, periprostetik membranlarda RANKL (receptor activator of nuclear factor-kappaB ligand) ve osteoprotegerin ekspresyonu ile karakterize edilen nükleer faktör-kB (RANK) ve RANK ligand (RANKL) reseptör aktivatörünün aktivasyonu yer alır. ${ }^{[6]}$ Bu durum, kemik implant ara yüzlerinde osteoklast aktivitesini artırır. Hastalar aktivite ile hafif-orta şiddette ağrı ile başvurabilir, ancak önemli kemik kaybına rağmen asemptomatik olabilirler. Dokuz yıllık süre boyunca periasetabular osteolizde ilerlemenin değerlendirildiği bir çalışmada, hastaların ya nispeten küçük hacimli osteolitik lezyonlar geliştirdiği ya da artan kırık riski ve komponent gevşemesi veya migrasyon ile ilerleyen geniş lezyonlara sahip olduğu görüldü. ${ }^{[8]}$ Ağrı, aseptik gevşemenin geç aşamalarına kadar görülmeyebilir; bu noktada ciddi kemik kaybı, revizyon cerrahisi prosedürünü zorlaştırabilir. Kemik grefti gerektiren karmaşık revizyon prosedürleri, daha uzun rehabilitasyon ve daha düşük fonksiyonel sonuçlar ile ilişkilidir. ${ }^{[9]}$ Osteolizin radyolojik bulguları; bazen sklerotik sınırlar veya kortekste incelme ile birlikte komponente bitişik radyolusent alanlar olarak gözlenir. Radyografiler ile osteolizin boyutu tam olarak anlaşılmayabilir ve tam boyutunu değerlendirmek için metal artefakt gideren bilgisayarlı tomografi (BT) veya manyetik rezonans (MR) görüntüleme gerekebilir. Teknesyum-99m (99 mTc) işaretli kemik taraması, sorunlu olgularda gevşemeyi ekarte etmek için yararlıdır ancak birincil tanı yöntemi olarak önerilmez. ${ }^{[10]}$ Osteoliz başlayan ancak asemptomatik olan ve radyografik olarak komponentleri stabil olan hastalara revizyon yapma kararı vermek zordur. Sınırlı osteolizi olan hastalar, ilerlemenin takibi için yıllık olarak takip edilmelidir. Asemptomatik, küçük ve ilerleyici olmayan lezyonlar genellikle tedavi gerektirmez. Ağrı, osteolitik lezyonların genişlemesi, kortikal düzensizleşme, komponentlerin gevşemesi veya instabilitesi ve periprostetik kırıklar, revizyon cerrahisi prosedürünün endikasyonlarıdır. Bisfosfonatlar ve nonsteroid antiinflamatuvar ilaçlar (NSAii) gibi farmakolojik ajanlar, hayvan modellerinde osteolitik süreci yavaşlatmak için kullanılmıştır. ${ }^{[11]}$ Hastalar üzerinde yapılan birkaç çalışmada bisfosfonatların osteolizin ilerlemesini yavaşlattı̆̆ını ve TKA'da periprostetik kemik yoğunluğunu iyileştirdiğini gösterilmiştir. ${ }^{[12]}$ Tümör nekroz faktörünü (TNF), IL-4 ve IL-10'u ve RANKL'ı hedefleyen immunglobulin monoklonal antikorları, osteolizi başlatan partikül kaynaklı enflamatuvar süreci hedeflemek için yararlı olabilir. ${ }^{[13]}$

\section{Enfeksiyon}

Enfeksiyon TKA'nın en kötü komplikasyonudur ve ağrılı TKA'sı olan her hastanın değerlendirilmesinde göz önünde bulundurulmalıdır. Erken revizyonun en sık nedenidir ve primer kalça artroplastilerinin \%0,3 ile \%3'ünde rapor edilmiştir. ${ }^{[14]}$ iş̧levin azalması, yaşam kalitesinin kötüleşmesi ve daha yüksek ölüm oranı ile ilişkilidir. Periprostetik kalça enfeksiyonu, tüm revizyonların yaklaşık \%15'ini oluşturur, instabilite ve aseptik gevşemeden sonra en yaygın üçüncü nedendir. Profilaktik antibiyotiklerin uygulanması enfeksiyon oranını azaltmıştır. Ancak artan antibiyotik direnci ve polimikrobiyal enfeksiyonlarla sonuçlanan gramnegatif mikroorganizmaların katılımı nedeniyle ampirik tedavi seçimi giderek daha karmaşık hale gelmektedir. Son çalışmalar, kalça revizyon artroplastisi geçiren hastalarda cilt florasının antimikrobiyal profilaksiye direncinin arttığını göstermiştir. ${ }^{[15]}$ Risk faktörleri arasında yaş, yetersiz beslenme, komorbiditeler, $\geq 30 \mathrm{~kg} / \mathrm{m}^{2}$ vücut kitle indeksi (VKi) ve uzun süreli hastanede kalış yer alır. ${ }^{[15]}$ Cerrahi risk faktörleri arasında uzamış ameliyat süresi (>150 dakika), kan transfüzyonu yapılması ve eş zamanlı bilateral artroplasti vardır. ${ }^{[16]}$ İmplante edilen proteze verilen lokal granülosit yanıtı, enfeksiyon 
için gerekli olan bakteri inokulumunu, özellikle de Staphylococcus'u büyük ölçüde azaltır.[16] Enfeksiyon; implant uygulama sırasında, hematojen yayılım, lokal bir kaynaktan komşu yayılım veya daha önce enfekte olmuş bir eklemde tekrarlamayla meydana gelebilir. Bu nedenle, periprostetik enfeksiyonlar klinik olarak oluşma zamanına göre sınıflandırılır. Ameliyat sonrası erken enfeksiyonlar ameliyattan sonraki ilk dört ile sekiz hafta içinde ortaya çıkar. Gecikmiş enfeksiyonlar ameliyattan sonra üç ay ile iki yıl arasında ortaya çıkar. Geç enfeksiyonlar cerrahi işlemden iki yıl sonra ortaya çıkar ve genellikle uzak bir bölgeden hematojen yayılımın bir sonucudur. ${ }^{[17]}$ Enfeksiyonla ilişkili tek bulgu, özellikle geç enfeksiyon veya düşük virülanslı organizmalarda, kalıcı ağrı olabilir. Bu nedenle, özellikle başka semptomların yokluğunda, enfeksiyondan şüphelenmek çok önemlidir. Amerikan Ortopedik Cerrahlar Akademisi (AAOS) 2010 yılında, periprostetik eklem enfeksiyonu tanısını aşağıdaki kriterlere göre standart hale getirmek için bir klinik uygulama kılavuzu geliştirmiştir: Eklem içine sinus yolu, eklemden elde edilen iki ayrı doku veya sıvı örneğinden kültürlenmiş bir patojenin elde edilmesi veya aşağıdaki altı maddeden dördünü içermesi yeterlidir (1, yüksek serum eritrosit sedimentasyon hızı [ESR] veya serum C-reaktif protein [CRP]; 2 , sinovyal sıvıda yüksek beyaz kan hücresi [WBC] sayısı; 3, yüksek sinovyal nötrofil yüzdesi [PMN, \%]; 4, gözle görülen püy; 5 , periprostetik doku veya sıvının bir kültüründe bir mikroorganizmanın izolasyonu; 6 , dört yüz kat büyütmede beş alanda büyütme alanı başına beş nötrofil bulunması). ${ }^{18]}$

Herhangi bir ağrılı TKA'da öncelikle ESR ve CRP tetkikleri istenmelidir. Her ikisi de negatif olduğunda, \%90'ı aşan bir duyarlılıkla periprostetik enfeksiyon ekarte edilebilir. ${ }^{[17]}$ Ameliyattan bir ay sonra ESR azalmaya başlar ve bir yıla kadar yüksek kalabilir. C-reaktif protein cerrahi işlemden sonra iki ile dört hafta içinde normale döner. Farklı değerler değerlendirilmiş, ESR için $22,5 \mathrm{~mm} /$ saat ve CRP için $1,35 \mathrm{mg} / \mathrm{L}$ eşik seviyeleri göz önüne alındığında, enfeksiyon tanısında biri pozitif ise \%96 duyarlılık ve \%77 özgüllük, her ikisi birden pozitif ise \%89 duyarlılık ve \%93 özgüllük göstermiştir. ${ }^{[19]}$ Enflamatuvar artritli hastalarda yüksek kan enflamatuvar değerleri romatizmal hastalık olarak değerlendirilmemeli ve enfeksiyon ekarte edilmelidir. Serum interlökin-6 (IL-6) düzeyinin $>10 \mathrm{pg} / \mathrm{mL}$ olması, henüz AAOS kılavuzlarında yer almamasına rağmen, \%100 duyarlılığa ve \%95 özgüllüğe sahiptir. ${ }^{[20]}$ Sinovyal sıvıdaki WBC sayımında 3.966 hücre/mL'yi veya $\% 80$ nötrofil yüzdesini aşması kronik periprostetik kalça enfeksiyonlarının teşhisi için bir eşik değer olarak rapor edilmiştir. ${ }^{[18]}$ Akut periprostetik eklem enfeksiyonunda (TKA'dan sonra altı hafta içinde) eşik değerlerin belirlenmesi daha zordur ve \%89 nötrofil ile 27.800 hücre/mL civarındadır. Etken ajanı bulmak ve antibiyotiklere duyarlılığını belirlemek için aerobik, anaerobik ve mantar kültürleri için sinovyal sıvı gönderilmelidir. Gram boyama düşük duyarlılığa sahiptir. Alfa-defensin, beta-defensin 3 ve katelisidin LL-37 septik gevşemeden aseptik gevşemeyi ayırt etmede yardımcı olabilecek tanı göstergeleridir. Radyografide, korteksin endosteal yüzeyinde düzensizlik, belirgin periost reaksiyonu veya yeni kemik oluşumu gibi gevşeme belirtileri görülebilir. Özellikle BT ve MR ile implant kaynaklı artefakttan dolayı septik ve aseptik gevşeme arasında ayrım yapmak zor olabilir. Bu gibi durumlarda, kemik sintigrafisi ve galyum taramaları gibi radyonüklid görüntüleme yöntemleri yararlı olabilir. Galyum taramasıyla birlikte tanı koyma oranı \%65 ila \%80'e varan bir duyarlılığa ulaşabilir. Bununla birlikte, kemik yeniden şekillenme alanları artan alım göstermeye devam etmektedir. Kombine bisfosfonat taramaları ve indiyum işaretli lökosit taramaları gibi en doğru yöntemler bile ameliyat sonrası birinci kadar asemptomatik eklemler çevresinde artan aktivite gösterebilir. Kombine lökosit ve kemik iliği görüntüleme bu noktada en yüksek duyarlılık ve özgüllüğe ulaşabilir. Kemik iliği görüntüleme için indiyum-111 (111 In) veya teknesyum-99 m (99 mTc) ile işaretli lökositlerin kullanılması, \%90 ile \%100 arasında bir tanısal duyarlılık ve özgüllüğe ulaşabilir. ${ }^{[21]}$

Periprostetik kalça enfeksiyonunun tedavisinde iki aşamalı revizyon artroplastisi altın standarttır. Periprostetik enfeksiyonda ömür boyu baskılama tedavisi; neden olan patojen düşük virülanslı, oral olarak uygulanabilen antibiyotiklere karşı yüksek duyarlılığa sahipse ve gevşeme belirtisi olmayan, cerrahi prosedür uygulanamayacak kadar ciddi tıbbi durumları olan uyumlu hastalar için bir seçenektir. Spesifik kriterler karşılandığında tek aşamalı revizyonlar da başarılı bulunmuş olsa da en yükssek başarı oranı (\%90), iki aşamalı revizyondur. Nadir durumlarda ve hayatı tehdit eden durumlarda son çare olarak rezeksiyon artroplastisi uygulanabilir. ${ }^{[17]}$

\section{İnstabilite}

TKA'yı takiben oluşan instabilite, hem hastalar hem de ortopedi ve travmatoloji uzmanları için önemli bir memnuniyetsizlik nedenidir. Çıkık, revizyon cerrahi prosedürünün en yaygın nedenlerinden biridir. Total kalça artroplastisini takiben çıkık riski implant tasarı$\mathrm{m}$ ı ve cerrahi teknikteki gelişmeler nedeniyle azalmıştır. Subluksasyonun teşhis edilmesi zordur, bu nedenle sıklıkla gözden kaçar ve hastaların \%2 ila \%5,5'inde meydana geldiği tahmin edilmektedir. ${ }^{[22]}$ Protez kalça çıkıklarının çoğu ilk altı hafta içinde ortaya çıkar ve neredeyse üçte biri tekrarlama eğilimindedir. Total kalça 
artroplastisinden sonraki ilk üç ile altı ay içindeki çıkıklar erken çıkık olarak kabul edilir ve en yaygın olanıdır (\%50-\%70). Sekonder çıkıklar TKA'dan 3-6 ay ve beş yıl arasında ortaya çıkar ve tüm çıkıkların \%15-20'sini oluşturur. Geç çıkıklar (TKA'dan >5 yıl sonra) genellikle polietilen aşınmasına bağlıdır ve ortalama oluşma süresi yaklaşık 11 yıldır. Çıkıkla ilişkili hasta faktörleri arasında >70 yaş, Amerikan Anestezi Derneği (ASA) skorunun $\geq 3$ ile sonuçlanan komorbiditeler, kadın cinsiyet, bağ gevşekliği, abduktor yetmezlik ve nöromusküler bozukluklar yer alır. Stabiliteyi belirleyen cerrahi faktörler arasında; yumuşak doku gerginliği, komponent pozisyonu, sıkışma, cerrahi yaklaşım ve lomber spinal füzyon öyküsü yer alır. Lumbopelvik esneklik, oturur pozisyonda TKA'nın stabilitesini artırır ve sıkışmayı önlemeye yardımcı olur. Çoğu çıkıkta, komponentin pozisyonu, asetabulum eğimi $\left(40^{\circ} \pm 10^{\circ}\right)$ ve anteversiyonu $\left(15^{\circ} \pm 10^{\circ}\right)$ Lewinnek güvenli bölgesi içindedir. Posterior yaklaşımlarda yapılan modern modifikasyonlar, çıkık riskini önemli ölçüde azaltmıştır. Anterior yaklaşım, daha yüksek kırık riski ve çok uzun öğrenme eğrisinin yanında düşük çıkık riski ile ilişkilidir. Revize edilmiş TKA (\%28'den fazla), primer TKA'ya (\%0,3 ila \%10) oranla daha yüksek bir çıkık oranına sahiptir. ${ }^{[22]}$ Baş boyun oranı, insert tipi ve offset gibi implant tasarım faktörleri çıkık riskini etkileyebilir. Daha büyük femur başının kullanılması, çıkık oranını azaltır. Çapraz bağlı polietilen, hacimsel aşınmayı önemli ölçüde azaltan 32 mm'den 36 mm'ye kadar femur başlarının kullanımına izin verir. ${ }^{[23]}$ Pozisyonel veya travmatik çıkık; implant pozisyonu, yumuşak doku gerginliği ve hareket açıklğının kapsamlı bir şekilde değerlendirilmesinden sonra rotasyon botu ile tedavi edilebilir. Tekrarlayan çıkıkların tedavisi, altta yatan etiyolojiye bağlıdır ve komponent pozisyonu, femoral offset ve bacak boyu uzunluğunun değerlendirilmesini içermelidir. Femoral ofsette 1 cm'den fazla kayıp, kalça abduktorlarındaki gerilim kaybına bağı instabiliteye neden olabilir. Polietilen aşınması sonucu meydana gelen geç çıkıklar, revizyon cerrahi prosedürünü gerektirir. ${ }^{[23]}$ TKA sonrası instabilite için cerrahi tedavi, bariz komponent malpozisyonu olmayan hastalarda genellikle ikinci hatta üçüncü çıkıktan sonra düşünülür. Cerrahi seçenekler, yumuşak doku gerilimini artırmak için modüler komponentlerin değiştirilmesini, bipolar veya tripolar artroplasti dâhil olmak üzere daha büyük baş çapına sahip implantların kullanımını veya asetabular dudak kullanımını içerir. Tekrarlayan veya açıklanamayan çıkıklar, yumuşak doku, trokanterik ilerletme veya kilitli insert kullanımından yarar görebilir. ${ }^{[24]}$

\section{Başarısız Metal-Metal Kalça İmplantları}

Kalça yüzey yenileme ve TKA'da metal-metal kullanımı, düşük aşınma oranlarına sahip oldukları iddia edildiğinden genç ve aktif hastalarda yaygın olarak kullanılmıştır. Büyük başlı, metal-metal yatakların polietilenden daha az aşınma sergiledikleri doğru olsa da polietilen gibi diğer aşınma parçacıklarından daha fazla sayıda, daha sitotoksik olan krom-kobalt iyonları ve parçacıkları yayar. ${ }^{[25]}$ TKA'da herhangi bir modüler bağlantıda korozyon meydana gelebilir, bu da metal iyonlarının salınmasına neden olur. Iyon seviyeleri aşınmayı yansıtır, metallozdan aseptik lenfosit baskın vaskülit ile ilişkili lezyon ve psödotümör oluşumuna kadar bir spektrumu içerebilir. Metal partiküllere karşı oluşan reaksiyonun, lokal yumuşak doku reaksiyonlarını indükleyebileceği teorik olarak ortaya konmuştur. ${ }^{[25]}$ Bu etkinin nedeninin doza bağımlı toksisite mi yoksa bir hasta grubundaki bağışıklık tepkisiyle mi oluştuğu henüz belirlenememiştir. Metal implantlara karşı olumsuz lokal doku reaksiyonunun prevalansı düşüktür ve bazı vaka sayısı yüksek çalışmalarda $\% 0,5$ ile \%1,5 oranları arasında tahmin edilmektedir. Metalpolietilen ve metal-seramik eklemleşme yüzeyleri için de olumsuz yumuşak doku reaksiyonları tanımlanmıştır. $^{[25]}$ Kandaki metal iyonlarının konsantrasyonları, metal-metal eklemleşmeden sonra ve implant gevşediğinde daha da yükselir. En yaygın başvuru nedeni, ameliyat sonrası rahatlama döneminin ardından kasık bölgesi ağrısının tekrarlamasıdır. Ağrılı metal-metal kalça protezi olan hastaların değerlendirilmesi zordur. Ayırıcı tanıda metal aşıı duyarlılığı ve aşınma düşünülmelidir. Eritrosit sedimentasyon hızı ve CRP, enfeksiyon olmasa bile, lokal doku reaksiyonunda da yükselebilir. Serum metal iyon seviyeleri, metal-metal eklemleşmesi olan hastaların değerlendirilmesini ve izlenmesini kolaylaştırır. Manyetik rezonans görüntüleme, özellikle klinik olarak ağrısı, iyon seviyeleri yüksek veya radyografik değişiklikleri olan hastaların değerlendirilmesinde yararlıdır. Bununla birlikte, yumuşak doku hasarını öngörmede tek başına serum metal iyon seviyeleri güvenilir değildir. Özellikle serum metal iyon seviyeleri yüksek olan asemptomatik hastalarda ve düşük serum metal iyon seviyeleri olan semptomatik hastalarda birçok faktörün dikkate alınması gerekir. Metal kalça implantı olan hastalar için, İngiliz cihaz uyarı kılavuzları; yılık klinik ve radyografik değerlendirmeyi, serum metal iyon analizini, semptomatik hastalar için gelişmiş görüntüleme yöntemlerinin kullanımını ve kobalt veya krom seviyesinin milyonda yediyi aşması durumunda üç ay içinde yeniden test yapılmasını önerir. ${ }^{[26]}$ İyi dizilime ve normal iyon seviyelerine sahip ağrılı metal-metal protezi olan hastalar, diğer ağrı etiyolojileri için araştırılmalıdır. Herhangi bir ağrı nedeni belirlenemezse, revizyon iyi bir seçenek olarak kabul edilir. Revizyondan altı hafta sonra, iyonlar başlangıç değerinden yaklaşık \%80 azalır ve revizyondan 12 hafta sonra yaklaşık $\% 90$ azalır. ${ }^{[27]}$ 


\section{Tendon Bozuklukları}

Enfeksiyon, gevşeme ve lomber omurga patolojisi dışlandıktan sonra, tendon bozuklukları her zaman düşünülmelidir. İliopsoas tendiniti, trokanterik bursit, abduktor tendinopati ve snapping (atlayan) kalça sendromu görülebilir ve ağrısız bir dönemden sonra gelişebilir. Total kalça artroplastisinden sonra iliopsoas tendiniti yaygın olarak görülür. illiopsoas tendiniti, hastaların \%4 kadarında press-fit ve çimentolu protezlerin kullanıldığı primer ve revizyon olgularında tanımlanmıştır. ${ }^{[28]}$ Asetabular komponentin pozisyonu, anterior osteofitler, asetabular vidalar, bacak uzunluk eşitsizliği ve çimento suçlanmıştır. Trokanterik bursit, artmış femoral offset ve bacak uzunluğu eşitsizliğine bağlanabilir. Semptomları gluteus medius ve minimusu içeren abduktor tendon yırtıkları ile benzerdir. Bu tür yırtıklar ameliyat öncesi, ameliyat sonrası veya cerrahi sırasında iyatrojenik kökenli olabilir. Tanı MR görüntüleme ile konulur. Tedavide ilk aşamada fizik tedavi önerilir. Ameliyatsız tedavinin başarısız olduğu ve günlük yaşam aktivitelerinin olumsuz etkilendiği hastalarda cerrahi yöntemler gereklidir. Seçilmiş olgularda bursektomi veya artroskopik abduktor tendon onarımı ile iliopsoas veya iliotibial bant gevşetme oldukça etkili olabilir. ${ }^{[28]}$

\section{Bacak Uzunluk Eşitsizliği}

Yapısal (gerçek) bacak uzunluk eşitsizliği alt ekstremitedeki uzunluk farkıdır ve fonksiyonel (görünür) bacak uzunluk eşitsizliği ise yumuşak doku kontraktürlerinden veya pelvik eğimden kaynaklanan alt ekstremitenin postüral asimetrisinden kaynaklanır. Total kalça artroplastisinden sonra bacak uzunluk eşitsizliğinden dolayı hasta memnuniyetsizliği, bir ortopedi ve travmatoloji uzmanına karşı dava açılmasının en yaygın nedenlerinden biridir. Total kalça artroplastisi uygulanan hastaların \%1 ila \%27'sinde 3 ile 70 $\mathrm{mm}$ (ortalama aralık, 3 ile $17 \mathrm{~mm}$ ) arasında bacak uzunluk eşitsizliği bildirilmiştir. On milimetrelik bacak uzunluk eşitsizliği çoğu hasta tarafından iyi tolere edilse de daha büyük bir eşitsizlik memnuniyetsizliğe, morbiditeye ve revizyon cerrahi prosedürüne yol açabilir. Bacak uzunluk eşitsizliğinin değerlendirilmesi, antevert femur boyununun gerçek bir anteroposterior görünümüne izin vermesi için alt ekstremitenin $20^{\circ}$ iç rotasyondayken supin pozisyonda çekilen anteroposterior pelvik radyografisi ile başlar. Hem fonksiyonel hem de gerçek bacak uzunluk eşitsizliğinin ilk tedavisi konservatiftir. Ayakkabı modifikasyonu ve fizik tedavi ile başlanır. Gerçek uzunluk farkı >2 cm olan ve kalıcı ağrısı olan hastalarda, riskler ve beklentiler kapsamlı bir şekilde tartışıldıktan sonra revizyon cerrahi prosedür gerekebilir. ${ }^{[29]}$

\section{Heterotopik Ossifikasyon}

Heterotopik ossifikasyon genellikle asemptomatik olmasına rağmen, kalça hareket açıkı̆̆ını kısıtlayarak kötü hasta sonuçları ve memnuniyetsizliğe yol açabilir. Yumuşak dokulara veya kemiğe uygulanan cerrahi travma ile oluşabilir. Histolojik olarak heterotopik ossifikasyon, akut enflamatuvar reaksiyon ve ardından yaklaşık altı ayda matür kemiğe ilerleme ile kırık iyileşmesine benzer bir karakter gösterir. 1973'te Brooker ve ark. tarafindan bir sınıflandırma tanımlandı. Evre 1, yumuşak dokulardaki kemik adalarını gösterir; evre 2, karşılıklı kemik uçları arasında $>1 \mathrm{~cm}$ 'lik bir boşluktur; evre $3,<1 \mathrm{~cm}$ 'lik bir boşluktur; evre 4, femur ve pelvis arasındaki tüm mesafeyi köprüleyen kemikleşmedir. Total kalça artroplastisi uygulanan hastaların \%3 ila \%7'sinde klinik olarak önemli heterotopik ossifikasyon gelişimi (3. ve 4. evre) tanımlanmıştır. Heterotopik ossifikasyon proflaksisi için, radyoterapi ve NSAii (non-steroid antienflamatuvar ilaç) kullanılmıştır. Bisfosfonatlar sadece heterotopik ossifikasyon oluşumunu erteler. ${ }^{[30]}$ Hasta risk faktörleri arasında erkek cinsiyet, yaş, heterotopik ossifikasyon öyküsü, ankilozan spondilit, yaygın idiyopatik hiperostoz, Paget hastalı̆gı ve romatoid artrit bulunur. Cerrahi riskler arasında; yumuşak doku disseksiyonunun boyutu, hematom gelişimi ve muhtemel kemik kalıntılarının olması sayılabilir. ${ }^{[31]}$ Primer veya revizyon TKA uygulanan yüksek riskli hastalarda, ameliyattan dört saat önce veya ameliyattan 72 saat sonra 7-8 Gray (Gy)'lik bir doz radyasyon tedavisi, indometazin uygulanmasından daha etkili profilaksi gibi görünmektedir. ${ }^{[32]}$ Standart indometazin dozu altı hafta boyunca günde 75 mg'dır ve eksizyon sonrasında tekrarlayan heterotopik ossifikasyonlarda profilaksi için radyasyon tedavisi ile kombine edilebilir. Heterotopik ossifikasyonun gelişmesinden sonra profilaktik tedavinin etkili olmadığı gösterilmiştir. ${ }^{[32]}$ Heterotopik ossifikasyona bağlı hareket kısıtılı̆ğının tedavisi, hastalığın olgunlaşma evresinde fizik tedaviden oluşur. Seçilmiş olgularda cerrahi tedavi gerekli olabilir, hareket açıklığını ve fonksiyonel sonucu iyileştirebilir.

\section{KAYNAKLAR}

1. Hanssen AD. Revision total hip arthroplasty: the painful hip. J Bone Joint Surg Am 2009;91 Suppl 5:22. Crossref

2. Department of Orthopaedics Sahlgrenska University Hospital. Annual Report 2003. The Swedish National Hip Arthroplasty Register; 2004.

3. Clohisy JC, Calvert G, Tull F, McDonald D, Maloney WJ. Reasons for revision hip surgery: a retrospective review. Clin Orthop Relat Res 2004;429:188-92. Crossref

4. Howie DW, Neale SD, Haynes DR, Holubowycz OT, McGee MA, Solomon LB, Callary SA, Atkins GJ, Findlay DM. Periprosthetic osteolysis after total hip replacement: molecular pathology and clinical management. Inflammopharmacology 2013;21(6):389-96. Crossref 
5. ArchibeckMJ,JacobsJJ, Roebuck KA, Glant TT. The basic science of periprosthetic osteolysis. Instr Course Lect 2001;50:185-95. https://pubmed.ncbi.nlm.nih.gov/11372314/

6. Clohisy JC, Frazier E, Hirayama T, Abu-Amer Y. RANKL is an essential cytokine mediator of polymethylmethacrylate particle-induced osteoclastogenesis. J Orthop Res 2003;21(2):202-12. Crossref

7. Sundfeldt M, Carlsson LV, Johansson CB, Thomsen P, Gretzer C. Aseptic loosening, not only a question of wear: a review of different theories. Acta Orthop 2006;77(2):177-97. Crossref

8. Howie DW, Neale SD, Stamenkov R, McGee MA, Taylor DJ, Findlay DM. Progression of acetabular periprosthetic osteolytic lesions measured with computed tomography. J Bone Joint Surg Am 2007;89(8):1818-25. Crossref

9. Jacobs CA, Christensen CP, Greenwald AS, McKellop $\mathrm{H}$. Clinical performance of highly cross-linked polyethylenes in total hip arthroplasty. J Bone Joint Surg Am 2007;89(12):2779-86. Crossref

10. Pfahler M, Schidlo C, Refior HJ. Evaluation of imaging in loosening of hip arthroplasty in 326 consecutive cases. Arch Orthop Trauma Surg 1998;117(4-5):205-7. Crossref

11. Shanbhag AS, Hasselman CT, Rubash HE. The John Charnley Award. Inhibition of wear debris mediated osteolysis in a canine total hip arthroplasty model. Clin Orthop Relat Res 1997;(344):33-43. Crossref

12. Zeng $Y$, Lai O, Shen B, Yang J, Zhou Z, Kang P, Pei F. A systematic review assessing the effectiveness of alendronate in reducing periprosthetic bone loss after cementless primary THA. Orthopedics 2011;34(4). Crossref

13. Childs LM, Goater JJ, O'Keefe RJ, Schwarz EM. Efficacy of etanercept for wear debris-induced osteolysis. J Bone Miner Res 2001;16(2):338-47. Crossref

14. Jafari SM, Coyle C, Mortazavi SM, Sharkey PF, Parvizi J. Revision hip arthroplasty: infection is the most common cause of failure. Clin Orthop Relat Res 2010;468(8):204651. Crossref

15. Mühlhofer HML, Deiss L, Mayer-Kuckuk P, Pohlig F, Harrasser $\mathrm{N}$, Lenze $U$, Gollwitzer H, Suren C, Prodinger P, VON EisenhartRothe R, Schauwecker J. Increased Resistance of Skin Flora to Antimicrobial Prophylaxis in Patients Undergoing Hip Revision Arthroplasty. In Vivo 2017;31(4):673-6. Crossref

16. Parvizi J, Della Valle CJ. AAOS Clinical Practice Guideline: diagnosis and treatment of periprosthetic joint infections of the hip and knee. J Am Acad Orthop Surg 2010;18(12):7712. Crossref

17. Zimmerli W, Trampuz A, Ochsner PE. Prosthetic-joint infections. N Engl J Med 2004;351(16):1645-54. Crossref

18. Parvizi J, Zmistowski B, Berbari EF, Bauer TW, Springer BD, Della Valle CJ, Garvin KL, Mont MA, Wongworawat MD, Zalavras CG. New definition for periprosthetic joint infection: from the Workgroup of the Musculoskeletal Infection Society. Clin Orthop Relat Res 2011;469(11):2992-4. Crossref

19. Greidanus NV, Masri BA, Garbuz DS, Wilson SD, McAlinden MG, Xu M, Duncan CP. Use of erythrocyte sedimentation rate and $C$-reactive protein level to diagnose infection before revision total knee arthroplasty. A prospective evaluation. J Bone Joint Surg Am 2007;89(7):1409-16. Crossref
20. Di Cesare PE, Chang E, Preston CF, Liu CJ. Serum interleukin-6 as a marker of periprosthetic infection following total hip and knee arthroplasty. J Bone Joint Surg Am 2005;87(9):1921-7. Crossref

21. Love C, Marwin SE, Palestro CJ. Nuclear medicine and the infected joint replacement. Semin Nucl Med 2009;39(1):6678. Crossref

22. Bou Monsef J, Parekh A, Osmani F, Gonzalez M. Failed Total Hip Arthroplasty. J Bone Joint Surg Rev 2018;6(11):e3. Crossref

23. Garbuz DS, Masri BA, Duncan CP, Greidanus NV, Bohm ER, Petrak MJ, Della Valle CJ, Gross AE. The Frank Stinchfield Award: Dislocation in revision THA. do large heads (36 and $40 \mathrm{~mm}$ ) result in reduced dislocation rates in a randomized clinical trial? Clin Orthop Relat Res 2012;470(2):351-6. Crossref

24. Parvizi J, Picinic E, Sharkey PF. Revision total hip arthroplasty for instability: surgical techniques and principles. Instr Course Lect 2009;58:183-91. https://pubmed.ncbi.nlm.nih. gov/19385532/

25. Germain MA, Hatton A, Williams S, Matthews JB, Stone MH, Fisher J, Ingham E. Comparison of the cytotoxicity of clinically relevant cobalt-chromium and alumina ceramic wear particles in vitro. Biomaterials 2003;24(3):469-79. Crossref

26. Medicines and Healthcare Products Regulatory Agency. All metal-on-metal (MoM) hip replacements: updated advice for follow-up of patients; 2017. https://www.gov.uk/drugdevice-alerts/all-metal-on-metal-mom-hip-replacementsupdated-advice-for-follow-up-of-patients

27. Ball ST, Severns D, Linn M, Meyer RS, Swenson FC. What happens to serum metal ion levels after a metal-on-metal bearing is removed? J Arthroplasty 2013;28(8 Suppl):53-5. Crossref

28. Capogna BM, Shenoy K, Youm T, Stuchin SA. Tendon Disorders After Total Hip Arthroplasty: Evaluation and Management. J Arthroplasty 2017;32(10):3249-55. Crossref

29. Pyrko P, Zuckerman J. Leg Length Discrepancy in Primary Total Hip Arthroplasty. Bull Hosp Jt Dis (2013). 2016;74(1):82-7. https://pubmed.ncbi.nlm.nih.gov/26977553/

30. Padgett DE, Holley KG, Cummings M, Rosenberg AG, Sumner DR, Conterato D, Galante JO. The efficacy of 500 CentiGray radiation in the prevention of heterotopic ossification after total hip arthroplasty: a prospective, randomized, pilot study. J Arthroplasty 2003;18(6):677-86. Crossref

31. Ahrengart L. Periarticular heterotopic ossification after total hip arthroplasty. Risk factors and consequences. Clin Orthop Relat Res 1991;(263):49-58. Crossref

32. Board TN, Karva A, Board RE, Gambhir AK, Porter ML. The prophylaxis and treatment of heterotopic ossification following lower limb arthroplasty. J Bone Joint Surg $\mathrm{Br}$ 2007;89-B(4):434-40. Crossref 